\title{
PENGEMBANGAN TTS (TABEL TENSES SEDERHANA) SEBAGAI ALAT BANTU METODE DRILLING PEMBELAJARAN BERBICARA BAHASA INGGRIS
}

\author{
Diand Mardiana, Euis Rabiatul Awaliah \\ Politeknik LP3I Jakarta \\ mardianadiand@gmail.com
}

\begin{abstract}
Teaching speaking as one of basic skill in English is one of the hardest process. It becomes a reason for the researcher to do a research which focus on inventing the best method for teaching speaking in English. So it motivates the researcher to contribute a solution to the problems by trying to invent quick and accurate method for teaching English' speaking. On this research, the researcher tries to design a special table name TTS (Tabel Tenses Sederhana). It used for teaching English speaking. After that the researcher tests the effectiveness of the teaching aid on two experimental classes. From that process, the researcher gets some feedbacks. The feedback is from the experimental class participants and also from the colleague. We hopes that the research will end with a formulation method or an effective teaching aid invention. The method on the research is perfective system approach. Perspective system is a study about a system by questioning: how a system entirely works properly and why it can work properly as it must. The spirit of TTS is not on the physical material as a teaching aid. The spirit of TTS is on the system and procedure. The form of TTS may be various. It can be as a real physical poster or it could be also as a simple note on the white board. Related to the response of the respondent, the majority of the participant having a positive response on the application of TTS on speaking class.
\end{abstract}

Keywords: Speaking Skill, TTS (Tabel Tenses Sederbana) Drilling Method

\begin{abstract}
ABSTRAK
Mengajarkan speaking sebagai salah satu keterampilan dasar dalam bahasa Inggris merupakan bagian paling sulit dalam proses pengajaran bahasa Inggris. Hal inilah yang membuat peneliti menjadi sangat tertarik untuk dapat memberikan kontribusi bagi masyarakat dengan mencari solusi terkait permasalahan tersebut. Dalam penelitian ini, peneliti mencoba mendesign sebuah tabel khusus yang disebut TTS (tabel tenses sederhana). Tabel TTS ini di uji dengan menggunakannya dalam pengajaran speaking. Selanjutnya peneliti akan melakukan uji kualitatif dengan melakukan wawancara kepada para objek dalam penelitian ini. Adapun alasan peneliti melakukan uji kualitatif dalam penelitian ini, dimaksudkan untuk memperoleh feed back. Baik dari responden maupun dari sejawat. Pardigma penelitian ini adalah pendekatan perspektif sistem. Perspektif sistem adalah suatu studi tentang sistem yang mempertanyakan: bagaimana sebuah sistem secara keseluruhan dapat berfungsi sebagaimana mestinya dan mengapa hal tersebut dapat berfungsi sebagaimana mestinya.Hasil dari penelitian ini menyimpulkan bahwa prinsipnya, ruh media pembelajaran TTS tidak terletak pada material fisik sebagai sebuah media pengajaran, namun justru terletak pada sistem dan prosedur. Media TTS bisa dalam bentuk apa saja: bisa poster dengan material khusus, soft-poster di media sosial dan layar komputer atau mungkin cukup dibuat seederhana diatas papan tulis dengan marker dan kapur. Terkait dengan respon responden, mayoritas peserta uji coba memberikan respon positif terkait dengan penggunaan media pembelajaran TTS dalam pengajaran speaking.
\end{abstract}

Kata kunci: Keterampilan Berbicara (Speaking), Tabel Tenses Sederhana (TTS) dan Metode Pengulangan (drilling)

Submitted Nov 15, 2020 | Revised Nov 27, 2020 | Accepted Des 03, 2020

\section{Pendahuluan}

Dalam proses pengajaran bahasa Inggris ketika sebuah materi hanya disampaikan dalam bentuk teori dan latihan hanya disampaikan dalam bentuk tulisan, pembelajaran menjadi kurang bermakna. Pembelajaran sesungguhnya telah kehilangan ruhnya. Salah satu dampaknya adalah kemampuan berbicara dalam Bahasa Inggris. Jika peserta didik langsung dilibatkan pada sebuah percakapan lengkap berbahasa Inggris, mereka akan mengalami kesulitan. Baik kesulitan karena kurangnya keterampilan mereka dalam berbahasa, maupun faktor mental blocking yang membuat mereka takut berbicara. 
EF Education First telah merilis hasil penelitian mereka EF English Proficiency Index pada 2019 lalu yang salah satunya menyatakan bahwa kemampuan rata-rata orang Indonesia berbicara dalam Bahasa Inggris ada di urutan 61 dari 100 negara yang diteliti. Laporan tersebut bersumber pada analisa data hasil tes bahasa Inggris dari sekitar 2,3 juta partisipan dalam EF Standard English Test diseluruh dunia yang dilakukan oleh EF.

EF Standard English Test adalah sebuah test kemampuan Bahasa Inggris yang adaptif milik lembaga EF yang telah disusun oleh para ahli untuk mengukur kemampuan Berbahasa Inggris sebagaimana testes lainya seperti : TOEIC, TOEFL dan IELTS. Seluruh konten pada EF Standard English Test telah diuji sebelumnya pada semua level CEFR. Common European Framework of Reference for Language atau CEFR adalah sebuah panduan yang digunakan untuk menjelaskan kemampuan berbahasa yang disetujui Dewan Eropa dan diakui sebagai standar internasional.

Metode pengajaran yang tepat diperlukan untuk lebih memaksimalkan kemampuan berbicara Bahasa Inggris para siswa. Terkait dengan metode pengajaran, dari sekian banyak metode, peneliti memfokuskan diri pada metode drilling (drilling method). Penelitian tentang penggunaan metode drilling dalam pengajaran bahasa asing sudah banyak dilakukan sebelumnya. Salah satunya adalah penelitian yang dilakukan oleh Sirajuddin Kamal dan Novita Triana, dosen pendidikan Bahasa Inggris FKIP Universitas Lambung Mangkurat yang berjudul "Penggunaan Metode Drill dalam Pembelajaran Bahasa Inggris". Penelitian tersebut masih bersifat sangat general dimana penelitian hanya difokuskan pada definisi drilling dan jenis-jenis drilling. Penelitian tersebut lebih merupakan pengungkapan tentang definisi dan jenis metode drill berdasarkan pendapat beberapa tokoh.

Kemampuan membentuk kalimat adalah salah satu fondasi dalam berbicara, selain fondasi-fondasi lainnya tentu saja. Drilling membuat kalimat dalam bentuk lisan akan sangat berpengaruh signifikan terhadap kemampuan berbicara. Terkait pembentukan kalimat, kata kerja (verb) memiliki peranan yang sangat penting. Menurut Frank 1972), kata kerja adalah bagian terkompleks dalam sebuah tuturan. Hal ini karena kata kerja adalah penentu utama dalam sebuah kalimat. Penggunaan dan penempatan kata kerja dapat menentukan jenis kalimat dan waktu. Sebaliknya penggunaan kata kerja juga dipengaruhi oleh pelaku (subject of the sentence). Dengan demikian menurut pendapat peneliti, penguasaan materimateri ini melalui proses drilling terus menerus akan berdampak sangat signifikan terhadap kemampuan berbicara. Pemikiran inilah yang sesungguhnya menjadi awal pijakan bagi peneliti melakukan pengembangan T'TS ini.

Mempelajari kemampuan dasar berbicara dalam bahasa asing secara sederhananya hanya tentang latihan mengkonstruksi kalimat dengan mengikuti kaidah-kaidah grammatical. Selanjutnya menggunakan kombinasi-kombinasi kata yang tersusun dalam frase dan kalimat tersebut dalam sebuah percakapan. Namun seringkali diantara proses pengajaran membuat kalimat dan conversation ada gap yang harus dilewati. Maksudnya, sekalipun sudah mampu menyusun kalimat tidak serta merta mahasiswa mampu menggunakannya dalam sebuah percakapan. Untuk mengetahui dan menganalisa penyebab gap tersebut diperlukan sebuah studi yang komprehensif. Hal tersebutlah yang menjadi tujuan dari penelitian ini. Selain itu, tentu saja melalui penelitian ini diharapkan akan tercipta sebuah rumusan metode dan solusi untuk menyelesaikan permasalahan tersebut. Sehingga target speaking bisa dicapai dengan baik dalam proses pembelajaran bahasa Inggris.

\section{Metode Penelitian}

Pendekatan dalam perspektif sistem digunakan sebagai paradigma penelitian ini. Patton secara teoritis mendefinisikan perspektif sistem sebagai "suatu studi tentang sistem yang mempertanyakan: bagaimana dan mengapa suatu sistem secara keseluruhan dapat berfungsi sebagaimana mestinya?" (Patton; 1980,78). Penekanan penelitian ini terletak pada analisa kinerja sistem untuk menjawab progres, daya guna dan efektivitas dari sistem yang dipertanyakan. Hal ini dilakukan dengan mengukur kualitas speaking mereka sebelum dan sesudah treatment. Efektifitas dari metode drilling yang digunakan dianalisa dengan melakukan wawancara kepada seluruh objek penelitian ini. Peneliti akan menganalisa 
persepsi pembelajar tentang bahasa Inggris sebelum dan sesudah menggunakan metode drilling yang dimaksud.

Rangkaian proses penelitian yang merupakan penelitian hibah dikti dalam skema PDP ini dimulai disepanjang tahun 2020. Namun karena permasalahan pandemik, maka waktu efektif yang sebenarnya dalam pengerjaan penelitian ini adalah sekitar 4 bulan terhitung Agustus sampai dengan November 2020. Pandemik tidak hanya berpengaruh pada scheduling, tapi juga terhadap kelas-kelas percobban dalam penelitian ini. Rencana awal kelas uji coba akan diselenggarakan secara serial diberbagai lembaga pendidikan di Bekasi. Kebijakan PSBB telah merubah semuanya, beruntung peneliti masih dapat menyelenggarakan kelas uji coba didalam suasana PSBB. Namun percobaan hanya memungkinkan dilaksanakan di PTQ Iqro. Sebuah pesantren tahfidz modern di Bekasi. Memungkinkan karena sekolah ini adalah sekolah yang masih beroperasional dengan protokol covid yang ketat pada saat itu. Peserta uji coba dibatasi hanya sekitar 22 orang yang dipilih secara acak dengan latar belakang dan level yang berbeda dengan dibagi kedalam 2 gelombang.

Terdapat sedikit perbedaan objek penelitian antara penelitian kuantitatif dan kualitatif. Pada penelitian kuantitatif yang menjadi objek penelitian diistilahkan sebagai populasi. Hal ini berbeda dengan penelitian kualitatif. Menurut Sugiyono (2008:49) dalam penelitian kualitatif tidak menggunakan istilah populasi, tetapi oleh Spradley dinamakan "social situation" yang terdiri dari tiga elemen yaitu: tempat, pelaku dan aktivitas yang berinteraksi secara sinergis. Penelitian ini diharapkan akan berlaku universal, sehingga populasi atau "social situation" yang menjadi objek dalam penelitian ini adalah seluruh orang yang mempelajari bahasa Inggris baik di tempat kursus maupun di dalam kampus. Khususnya orang-orang atau mahasiswa yang mempelajari berbicara dalam bahasa Inggris (speaking).

Dalam penelitian kuantitatif, kualitas instrument berkenaan dengan validitas dan reliabilitas instrument. Sedangkan dalam penelitian kualitatif, dimana yang menjadi instrument adalah peneliti sendiri. Sehingga bisa dikatakan bahwa peneliti adalah alat dari penelitian itu sendiri. Ada berbagai instrumen yang digunakan untuk mengumpulkan data dalam penelitian ini antara lain: wawancara dan observasi. Wawancara akan dilakukan baik secara terstruktur maupun secara semi-terstruktur. Observasi yang dilakukan adalah teknik observasi partisipatif. Observasi seperti ini dipilih agar peneliti lebih dekat terhadap objek penelitian. Setiap permasalahan dan hal-hal penting lainnya dapat ditemukan secara langsung dengan keterlibatan peneliti dalam proses pembelajaran. Hal ini harus dilakukan karena kajian kualitatif sangat dinamis. Permasalahan yang dikaji sangat berkembang sehingga peneliti harus masuk kedalam lapangan untuk memperoleh seluruh informasi penting.

Setelah pengumpulan data, proses selanjutnya adalah analisa data. Dalam penelitian ini, sejak awal pengumpulan data, proses analisa sudah dapat dilaksanakan. Namun setelah peneliti memahami fenomena dalam objek penelitian ini, maka proses penganalisaan menjadi lebih fokus lagi. Alur pemikiran dalam penelitian ini akan mulai tergambar menjadi lebih jelas lagi. Data-data kasar yang muncul dari lapangan kemudian akan ditransformasi menjadi data jadi yang siap disajikan. Proses reduksi ini akan diakukan secara terus menerus selama proses pengumpulan data berlangsung dalam penelitian ini. Setelah data direduksi menjadi cukup mudah dan sederhana untuk dipahami, langkah selanjutnya adalah penyajian data. Maksudnya menyajikan sekumpulan informasi yang tersusun dengan rapih sehingga memungkinkan adanya penarikan kesimpulan dan pengambilan tindakan. Penyajian data akan disampaikan dalam bentuk teks naratif. Hal ini dilakukan untuk menggabungkan informasiinformasi yang tersusun dalam bentuk yang padu. Setelah data dapat disajikan dengan baik, langkah terakhir adalah penarikan kesimpulan. Kesimpulan akhir dari penelitian ini diperoleh setelah proses terakhir ini. Sejak awal proses penelitian, dari memulai pengumpulan data, analisa kualitatif akan mulai dilakukan. Misalnya dengan kegiatan mencari makna, pola-pola dari fenomena yang terungkap, alur sebab-akibat, penjelasan berbagai pihak, penjelasan teori yang ada dan konfigurasi-konfigurasi yang muncul. 


\section{Hasil dan Pembahasan}

1. Gambaran Dasar

Tabel Tenses Sederhana selanjutnya disingkat menjadi TTS adalah sebuah poster yang berisi rangkuman singkat struktur dasar kalimat dalam Bahasa Inggris. Peneliti seringkali menyebutnya sebagai "Basic Understanding”. Sebagaimana kita pahami, struktur dasar kalimat sederhana dalam bahasa Inggris hanyalah: subjek (S), predikat (P) dan komplemen (C). Pada dasarnya tabel ini hanya menunjukan perubahan predikat mengikuti tenses dan fungsinya. Dengan melihat tabel TTS ini, diharapkan siswa dapat terbantu dalam mengkonstruksi kalimat-kalimat baik dalam drilling tertulis, terlebih dalam drilling speaking.

Prinsip kerja dari penggunaan media T'TS ini sejalan dengan pendapat John Dewey (2004) tentang pendidikan "orang belajar dari apa yang dikerjakannya”. Maksudnya dengan penggunaan media TTS ini para peserta didik diajak memahami aturan-aturan dalam Bahasa Inggris dengan "mengerjakan" latihan membentuk kalimat dengan arahan guru sebagai fasilitator dan T'TS sebagai kompas.

2. Poster Tabel Tenses Sederhana (TTS)

Tabel ini terdiri tiga kolom, yaitu kolom S (subject), P (predicate) dan C (complement). Kolom subject hanya diwakili subject pronoun ( I, you, they, we, he, she dan it), karena pada dasarnya semua subject bisa diwakili oleh subject pronoun (I, you, they, we, he, she dan it).

\begin{tabular}{|c|c|c|c|}
\hline $\mathbf{S}$ & \multicolumn{2}{|c|}{$\mathbf{P}$} & C \\
\hline \multirow{2}{*}{ I } & \multicolumn{2}{|c|}{ V1 / V1+s,es } & \multirow{2}{*}{ Adv of Time } \\
\hline & & & \\
\hline \multirow{2}{*}{ You } & & & \\
\hline & Can & \multirow{5}{*}{ V1/be } & \multirow{2}{*}{ Adv of Place } \\
\hline \multirow{2}{*}{ They } & Will & & \\
\hline & Must & & \\
\hline \multirow{2}{*}{ We } & Should & & \multirow{2}{*}{ Adv of Manner } \\
\hline & have to & & \\
\hline \multirow{2}{*}{$\mathrm{He}$} & & & \multirow{2}{*}{ Object } \\
\hline & & & \\
\hline \multirow[b]{2}{*}{ She } & \multicolumn{2}{|c|}{ was / were } & \\
\hline & & & Object Pronoun \\
\hline \multirow{2}{*}{ It } & have & \multirow{2}{*}{ V3/been } & \\
\hline & has & & \multirow{2}{*}{ Direct Object } \\
\hline \multirow{2}{*}{ pronoun } & & & \\
\hline & is, are, am & \multirow{2}{*}{ Ving/being } & \\
\hline \multirow{2}{*}{$\begin{array}{c}\text { Demonstrative } \\
\text { Word }\end{array}$} & was, were & & \multirow{2}{*}{ Indirect Object } \\
\hline & & & \\
\hline \multirow{2}{*}{ noun } & \multirow{2}{*}{\multicolumn{2}{|c|}{ Regular/Irregular Verb }} & \\
\hline & & & \\
\hline
\end{tabular}

Gambar 1. Contoh Tabel T'TS 
Kolom P (predicate) terdiri dari Verb 1 (simple present), Modal + V1, Verb 2 (simple past), have/has + $\mathrm{V} 3$, to be $+\mathrm{V}$ ing, dan lain-lain. Pada dasarnya kolom ini digunakan untuk menjelaskan kalimat-kalimat yang bersifat routine, general truth, bisa, akan, sebaiknya, harus, past time activity, sudah dan sedang. Penjelasan dari setiap fungsi pola kalimat itu harus disampaikan sebelum melakukan drilling. Ketika peserta didik sudah memahaminya, baru lakukan drilling supaya mereka dapat lebih mendalaminya dan menggunakannya dalam berbagai variasi kalimat.

Adapun kolom C (complement) dapat disampaikan jika diperlukan. Kolom ini terdiri dari berbagai part of speech yang memungkinan berada disini seperti object dan berbagai adverb. Kecuali adverb of frequency yang memang peletakannya sedikit unik.

3. Cara Kerja

Mempelajari suatu bahasa pada dasarnya adalah belajar mengkonstruksi sebuah kalimat. Diawali dari kalimat dasar dilanjutkan dengan kalimat yang semakin komplek. Diawali dengan kalimat baku yang gramatikal dilanjutkan dengan kalimat-kalimat yang lebih idiomatis. Dengan demikian jika seseorang telah mampu menyusun kalimat dalam sebuah bahasa, maka dia telah menguasai bahasa tersebut. Minimal dalam level awal-menengah.

Kalimat didefinisikan sebagai gabungan beberapa kata / frase yang terdiri dari subjek (S) dan predikat (P). Adapun komplemen (C) adalah tambahan yang membuat sebuah kalimat menjadi semakin lengkap. Karena posisinya sebagai tambahan, komplemen hanyalah pelengkap. Sebuah kalimat tanpa komplemen masih dapat dikatakan sebagai sebuah kalimat. Dengan demikian, pada level awal komplemen kalimat dapat dilewati terlebih dahulu sehingga peserta dapat fokus pada subjek dan predikat dari kalimat.

Cara kerja tabel ini adalah dengan berdasarkan pada definisi kalimat seperti penjelasan diatas. Drilling tahap awal dimulai dengan hanya kolom subjek dan predikat. Dengan fokus pada subjek dan predikat saja, peserta didik akan merasa dimudahkan. Selanjutnya subjek dari kalimat juga sangat sederhana. Kita bisa sampaikan bahwa subjek dari kalimat dapat dikenali dengan mudah karena subjek pastilah noun atau demonstrative word. Bahkan semuan subjek bisa disederhanakan dan diganti menjadi subject pronoun (kata ganti subjek). Cara kerja penggunaan subjek ini harus dijelaskan dengan rinci. Hal ini penting karena akan sangat berpengaruh dalam pembentukan kalimat dalam bahasa Inggris. Misalnya dalam pemilihan kata kerja dengan $-\mathrm{s}$ atau tanpa $-\mathrm{s}$ pada kalimat routine activity (simple present) atau penggunaan have dan has pada kalimat present perfect.

Pembelajaran dengan TTS hanya membahas tentang subjek sekitar 20\% sisanya 70\% menjelaskan predikat dan perubahannya. Meskipun hanya pelengkap, komplemen juga perlu dijelaskan meskipun proporsinya sekitar $10 \%$. Pembahasan dan drilling tentang predikat menjadi sangat signifikan. Perubahan predikat sangat berpengaruh terhadap makna dan fungsi kalimat. Predikat kalimat dalam bahasa Inggris adalah kata kerja (verb) dan berbagai kombinasinya. Dengan mempelajari kombinasi kata kerja sebagai predikat dari kalimat, peserta akan dapat mempraktikan variasi tenses dalam percakapan. Penguasaan grammar (tenses) dapat dilakukan dengan mellalui latihan speaking yang berulang-ulang.

Seringkali ada gap antara pembelajaran tenses dan praktik speaking. Hal ini terjadi karena seringkali peserta didik belajar tenses hanya dari tabel rumus tanpa di barengi dengan penjelasan yang detail serta praktik langsung dalam speaking, Tabel TTS ini mencoba menyederhanakan pola dan menggabungkan antara penjelasan grammar dan praktik speaking. Dengan tabel ini, peserta didik juga melakukan studi komparasi atara satu pola dengan pola lainnya. Dengan demikian pemahaman tenses dan fungsinya akan diperoleh secara lebih mendalam.

Seringkali juga kita temukan peserta didik yang menguasai tenses dengan baik tapi masih kesulitan menggunakannya dalam percakapan. Hal ini terjadi karena ada materi yang terputus antara materi mengenai tenses (grammar) dengan materi speaking. Keduanya terpisah dan tidak terintegrasi dengan baik. Hal ini lah yang sedang kita coba tanggulangi dengan mengintegrasikan keduanya.

4. Metode Drilling Berbasis Tabel TTS

Sebelum digunakan, instruktur metode ini perlu menjelaskan seluruh pola yang ada dalam tabel TTS disertai cara penggunaannya dalam kalimat. Ada beberapa hal dasar yang perlu disampaikan pula 
terkait dengan "Basic Understanding” pada saat drilling dengan TTS dilakukan antara lain: Part of Speech, Verb dan perubahannya, Tenses dan fungsinya, Gerund dan to-infinitive, Compound dan Complex Sentences.

Berikut ini adalah variasi kalimat yang bisa dilatihkan dengan menggunakan media pembelajaran TTS melalui metode drilling : Routine Activity/General Truth (Simple Present), Mengandung Modal (Modal), Kejadian Lampau (Past Simple), Mengandung makna "sudah" atau "belum"(Perfect), Mengandung makna "sedang" (Continuous), Kalimat Pasif (Passive Voices), Kalimat Majemuk (Complex Sentence).

Proses pengajaran tenses - grammar tidak lagi mengambang, tapi terintegrasi dengan pelatihan speaking. Peserta didik belajar tata bahasa sekaligus dengan mempraktikannya dalam materi drillingspeaking. Dengan demikian sekali treatment akan dapat memberikan pemahaman tata bahasa sekaligus melatih kemahiran berbicara.

\section{Proses Pengujian Media Pembelajaran TTS}

Sebagaimana dijelaskan dalam bagan alur penelitian, setelah proses studi literasi sehingga menghasilkan design awal media pembelajaran TTS. Langkah berikutnya adalah pengujian. Hal ini dilakukan untuk menguji efektivitas dan kehandalan objek penelitian, sekaligus salah satu langkah untuk memperoleh feedback dalam melakukan evaluasi.

Proses uji coba dilakukan dihadapan peserta didik tingkat remaja dengan kemampuan berbahasa Inggris dilevel menengah ke bawah. Dari proses ini, peneliti dapat menyimpulkan bahwa peserta uji coba hampir diatas 90\% merasa antusias. Mereka merasa tertarik dengan penggunaan media pembelajaran ini sebagai hal yang baru.

Dari proses ini diperoleh dua masukan dari sumber yang berbeda. Pertama persepsi peserta uji coba yang diperoleh dengan cara menyebarkan kuisioner kepada peserta uji coba dan interview langsung di dalam dan di luar proses kelas uji coba. Kedua adalah pendapat profesional dari kolega mengajar. Pendapat dan masukan profesional diperlukan untuk mendapatkan masukan yang memiliki dasar teoritis yang kuat sebagai sebuah metode pengajaran.

Dalam kondisi pandemik seperti ini, pengujian harus dilakukan dengan segala keterbatasan. Penggunaan daring bisa menjadi opsi sebenarnya. Namun kami mempertimbangkan tingkat keefektifannya. Pertama peneliti memerlukan respon peserta uji coba secara langsung. Respon langsung dapat menjadi sebuah masukan membangun bagi peneliti dalam mengembangkan TTS ini. Kedua keterbatasan media pembelajaran daring yang dimiliki para peserta dilingkungan kami menjadi pertimbangan lainnya.

Setelah mempertimbangkan hal-hal tersebut, peneliti mencoba mengkombinasikan metode daring dan luring secara bersamaan. Peneliti bekerjasama dengan sebuah pesantren yang masih melakukan proses belajar dan mengajar. Mereka melakukan proses ini dengan protokol kesehatan yang ketat.

Kelas uji coba dilakukan di dua kelas. Ini dilakukan dalam rangka protokol kesehatan ditengah pandemik untuk mengurangi jumlah peserta yang terlibat proses uji coba dalam satu waktu. Setiap kelas terdiri dari 11 siswa yang dipilih secara random sehingga total peserta menjadi 22 dengan latar belakang kelas dan kemampuan bahasa Inggris yang berbeda-beda. Setiap kelas uji coba tersebut masing-masing mendapatkan treatment pengajaran speaking dengan metode drilling menggunakan media pengajaran TTS selama masing-masing 1,5 jam.

Adapun proses observasi yang melibatkan rekan sejawat, kami lakukan secara daring. Dengan pertimbangan, bahwa rekan sejawat memerlukan waktu yang cukup untuk dapat menghasilkan pendapat yang baik, berbasis teori dan tentusaja membangun, pendekatan luring dirasa sudah cukup.

Teknisnya, peneliti mempresentasikan terlebih dahulu gambaran dasar dari penelitian ini kepada para kolega. Khususnya objek dalam penelitian ini, yakni Media pembelajaran TTS. Selanjutnya, proses pengajaran uji coba dikelas direkam dalam bentuk video. Kemudian peneliti mengirimkannya kepada kolega untuk ditonton, dianalisa dan dikomentari. Pendapat profesional berupa opini kolega ini 
selanjutnya dikirimkan kepada peneliti. Setelah mendapat masukan dari dua pihak berbeda yakni dari pihak pengajar dan pembelajar, proses analisa dilanjutkan.

6. Persepsi Tingkat Kesulitan

Dalam pengembangan media pengajaran TTS ini, peneliti mencoba menerima masukan dari berbagai pihak sebagai dasar dalam melakukan develeopment dan improvement. Persepsi para pelajar atau pihak yang akan belajar dengan media ini, sebagai pihak yang sangat terkait dengan penggunaan media ini sangatlah penting untuk mengukur sejauh mana tingkat keefektifan media pengajaran ini dalam proses kegiatan belajar mengajar.

Namun demikian, sebagaimana saya sampaikan diawal bahwa penelitian ini bukanlah penelitian kuantitatif yang terfokus mengukur variabel-variabel tertentu dengan metode statistik. Penelitian ini adalah penelitian kualitatif yang terfokus dalam penganalisaan dan pengembangan sebuah sistem sehingga pemaparan mengenai hal ini hanya menggunakan statistik dasar saja.

Untuk mengambil data ini peneliti menggunakan kuisioner tertutup. Peneliti memlih kuisioner tertutup untuk memfokuskan pembahasan pada hal-hal tertentu saja. Terlebih data yang diinginkan hanyalah beberapa informasi persepsi peserta seperti: Tingkat Kesulitan Penggunaan TTS, Kaitan Penggunaan TTS Terhadap Pemahaman Grammar, Kaitan Penggunaan TTS Terhadap Kemampuan Speaking, Analisa Kelemahan dan Kekuatan. Selain itu peneliti juga meminta masukan berupa masukan pribadi untuk pengembangan lebih lanjut.

7. Persepsi Tingkat Kesulitan Responden

Berdasarkan data statistika yang kami terima 55\% responden merasa mempelajari Bahasa Inggris menjadi mudah dan 14\% lainnya merasa menjadi sangat mudah dengan penggunaan media pembelajaran TTS ini. Prosentasi responden yang menganggap penggunaan media ini biasa-biasa saja ada sebesar 31\% dan tidak ada responden yang merasa sulit dalam penggunaan media pembelajaran TTS ini.

Tabel 1. Tingkat Kesulitan Berdasarkan Persepsi Responden

\begin{tabular}{cccccc}
\hline Sangat Sulit & Sulit & Biasa Saja & Mudah & Sangat Mudah & Total Responden \\
\hline $0 \%$ & $0 \%$ & $31 \%$ & $55 \%$ & $14 \%$ & $100 \%$ \\
\hline
\end{tabular}

Berdasarkan informasi ini, menunjukan bahwa media ini akan sangat membantu masyarakat khususnya para pelajar dalam menguasai dan memahami Bahasa Inggris. Penyampaian materi gramamar tanpa penjelasan yang gamblang dan runut hanya akan mempersulit siswa. Dengan penggunaan media ini penyampaian materi tata bahasa menjadi lebih sistematis dan gradual.

8. Persepsi Penggunaan T'TS Terhadap Pehamanan Grammar

Tabel 2 dibawah menunjukan hanya 4\% saja responden yang menyatakan bahwa penggunaan media TTS dalam pengajaran speaking tidak membantu mereka memahami grammar. Selebihnya 18\% menyatakan biasa, $46 \%$ menyatakan membantu dan ada 32\% menyatakan sangat membantu dalam memahami grammar. Perlu diketahu bahwa yang dimaksud grammar disini adalah variasi pola kalimat atau tenses.

Tabel 2. Persepsi Penggunaan TTS Terhadap Pehamanan Grammar

\begin{tabular}{cccccc}
\hline $\begin{array}{c}\text { Sangat Tidak } \\
\text { Membantu }\end{array}$ & $\begin{array}{c}\text { Tidak } \\
\text { Membantu }\end{array}$ & Biasa Saja & Membantu & $\begin{array}{c}\text { Sangat } \\
\text { Membantu }\end{array}$ & $\begin{array}{c}\text { Total } \\
\text { Responden }\end{array}$ \\
\hline $0 \%$ & $4 \%$ & $18 \%$ & $46 \%$ & $32 \%$ & $100 \%$ \\
\hline
\end{tabular}

Jadi dapat disimpulkan ada 78\% responden menyatakan sangat terbantu menguasai grammar dengan penggunaan media ini. Artinya penggunaan media TTS dalam pengajaran atau pemahaman grammar pagi para responden berada diatas $50 \%$ bahkan diatas $75 \%$ sehingga bisa dikatakan cukup signifikan membantu memahami grammar.

Uniknya, meskipun media pengajaran ini didesign untuk melatih speaking atau kemampuan berbicara. Namun karena drilling speaking dilakukan dengan berpedoman pada daftar variasi pattern 
struktur kalimat yang disusun berdasarkan fungsi bahasa, hal inilah yang membuat para responden menjadi mudah memahami grammar dasar khususnya tenses.

9. Persepsi Penggunaan TTS Terhadap Kemampuan Berbicara

Persepsi positif para responden terkait dampak penggunaan media TTS dalam pengajaran ternyata sampai 96\%. Responden yang menyatakan sangat membantu mencapai angka $32 \%$, sedangkan yang menyatakan cukup membantu ada $64 \%$. Sisanya berpendapat netral ada sebesar 4\%. Tidak ada satupun responden yang menyatakan bahwa penggunaan media ini tidak membantu atau bahkan sangat tidak membantu.

Tabel 3. Persepsi Penggunaan TTS Terhadap Kemampuan Berbicara

\begin{tabular}{cccccc}
\hline $\begin{array}{c}\text { Sangat Tidak } \\
\text { Membantu }\end{array}$ & $\begin{array}{c}\text { Tidak } \\
\text { Membantu }\end{array}$ & Biasa Saja & Membantu & $\begin{array}{c}\text { Sangat } \\
\text { Membantu }\end{array}$ & $\begin{array}{c}\text { Total } \\
\text { Responden }\end{array}$ \\
\hline $0 \%$ & $0 \%$ & $4 \%$ & $64 \%$ & $32 \%$ & $100 \%$ \\
\hline
\end{tabular}

Dalam kelas speaking, penggunaan media TTS sesungguhnya tidak direkomendasikan untuk digunakan seterunya. Pada pertemuan awal sebagai bentuk refreshment sangatlah disarankan. Selanjutnya media ini digunakan untuk pengingat ketika ada peserta mengalami kesulitan dalam mengkonstruksi sebuah kalimat dalam bahasa Inggris.

10. Analisa Kelemahan

Dalam pengembangan media TTS, analisa kelemahan mutlak diperlukan. Berikut adalah tabel yang menunjukan beberapa kelemahan media TTS ini,

Tabel 5. Analisa Kelemahan

\begin{tabular}{lcc}
\hline \multicolumn{1}{c}{ Permasalahan } & \multicolumn{2}{c}{ Responden } \\
& Jumlah & Persen \\
\hline Tidak memiliki kosakata & 4 & $18 \%$ \\
Tidak menghafalkan kata kerja & 8 & $36 \%$ \\
Sulit memahami tabel TTS & 6 & $27 \%$ \\
Metode yang monoton dan membosankan & 10 & $45 \%$ \\
Kelemahan lainnya __ kurang lengkap__ & 1 & $5 \%$ \\
\hline
\end{tabular}

Tabel tersebut menunjukan 4 orang atau 18\% responden berpendapat belajar dengan penggunaan TTS memerlukan kosakata yang cukup. Kemudian ada sekitar 8 orang atau 36\% responden berpendapat belajar dengan penggunaan media TTS harus menghafal kata kerja dan perubahannya. Selanjutnya ada 6 orang atau 27\% berpendapat bahwa tabel TTS ini sulit dipahamai.

Hampir setengah jumlah peserta, 10 orang atau sekitar 45\% menyatakan metode ini cukup monoton dan membosankan. Hal ini menjadi catatan kami dalam penelitian ini. Drilling dengan penggunaan TTS memang akan sangat membosankan jika dilakukan secara terus menerus. Oleh karena itu kami menyarankan agar pendekatan pengajaran ini hanya dilakukan diawal sebagi refreshment atau disela-sela waktu tertentu saja dalam proses pengajaran. Artinya pengajar harus sangat paham mengkombinasikannya dengan berbagai aktifitas dalam kegiatan pengajaran.

Masukan ini akan menjadi feed back utama dalam penelitian-penelitian lanjutan. Mencegah kebosanan juga dapat dilakukan dengan menggabukan proses pengajaran dengan kegiatan lain seperti berbagai game komunikatif. Selanjutnya bahasan ini akan menjadi fokus peneliti dalam pengembangan metode yang akan digunakan dalam pengaplikasian media pengajaran T'TS.

11. Analisa Kekuatan

Sisi kekuatan perlu diidentifikasi untuk kemudian dilakukan penguatan sehingga menjadi sebuah keunggulan yang membuat sebuah metode atau produk layak digunakan sepanjang waktu. Feedback dalam proses improvement tidak harus berupa kelemahan, tapi juga bisa berupa informasi tentang kekuatan. 
Tabel 6. Analisa Kekuatan

\begin{tabular}{lcc}
\hline \multirow{2}{*}{ Kelebihan } & \multicolumn{2}{c}{ Responden } \\
& Jumlah & Persen \\
\hline Mudah dipahami & 10 & $45 \%$ \\
Metode yang sederhana & 10 & $45 \%$ \\
Membantu memahami tenses & 10 & $45 \%$ \\
Sangat membantu kemampuan speaking & 16 & $73 \%$ \\
Kelebihan lainnya _memudahkan mempelajari bahasa Inggris__ & 1 & $5 \%$ \\
\hline
\end{tabular}

Ada 10 responden atau sekitar $45 \%$ dari seluruh responden yang mengatakan bahwa penggunaan media pengajaran ini memiliki kelebihan mudah dipahami. Begitupula yang berpendapat bahwa metode ini simple atau sederhana dan berpendapat mampu membantu mereka cepat memahami tenses ada sekitar $45 \%$ dari seluruh responden. Sedangkan $73 \%$ dari seluruh responden berpendapat bahwa penggunaan media ini telah membantu mereka meningkatkan kemampuan speaking lebih baik lagi, kemudian ada satu orang responden memberikan pendapat lain diluar pertanyaan tertutup.

\section{Opini Kolega}

Opini rekan sejawat diperlukan untuk lebih menguatkan temuan-temuan dalam peneelitian ini. Pendapat dari sisi teoritis dan praktis dari para profesional yang telah lama berkecimpung dalam dunia ELT (English Language Training) baik dilingkungan pendidikan formal maupun pendidikan nonformal. Pendapat mereka akan menguatkan dan mempertajam berbagai temuan dalam penelitian ini.

Sebelum memberikan pendapat profesionalnya, para sejawat yang memberikan opini profesionalnya telah mendapatkan penjelasan gamblang tentang objek dalam penelitian ini. Selain itu mereka telah mengobservasi proses percobaan dikelas uji coba.

Opini para kolega ini kami gambarkan dalam bentuk kualitatif deskriptif. Pilihan ini peneliti ambil dengan keyakinan bahwa kualitas pendapat profesional tidak ditentukan oleh jumlah. Dalam sebuah opini profesional, yang terpenting adalah kualitas dan kedalaman pendapat tersebut bukan pada besaran dan jumlah para kolega yang berpendapat.

\section{Penamaan}

Penamaan adalah hal pertama yang peneliti tanyakan kepada rekan sejawat. Nama menggambarkan segalanya. Penamaan yang tepat akan sangat berpengaruh dengan persepsi masyarakat. Penamaan yang singkat dan sederhana namun cukup menggambarkan semangat dan konten dalam media pengajaran ini akan sangat memudahkan setiap orang untuk mengingatnya.

Awalnya, salah seorang rekan mengira bahwa penelitian ini adalah penelitian tentang penggunaan crossword atau TTS ( Teka Teki Silang) dalam pengajaran. Hal ini sangat mungkin terjadi karena singkatan TTS yang berarti teka teki silang memang sudah lebih dulu populer. Namun dengan adanya istilah ini lebih awal, akan memudahkan kita mengingatnya dengan mengkaitkan istilah yang telah lebih populer sebelumnya.

\section{Media Pembelajaran TTS dalam Pelatihan Speaking}

Rekan pertama berpendapat bahwa proses drilling sangat membantu siswa dengan level dasar dalam kemampuan bahasanya. Jika dilakukan secara bersama-sama akan membantu siswa menaikan rasa percaya dirinya. Menayakan pada setiap siswa setelah melakukan drilling bersama-sama adalah sebuah proses yang sangat baik untuk memastikan bahwa setiap anak sudah memahami materi yang diberikan.

Rekan berikutnya juga berpendapat bahwa tabel TTS dan drillingnya akan sangat membantu proses pelatihan speaking. Menurutnya lagi, dengan bantuan tabel TTS ini peserta pelatihan akan dimudahkan mengingat susunan berbagai kalimat sederhana dalam Bahasa Inggris.

Pada dasarnya fungsi tabel ini semacam kompas dalam berbicara. Selama ini dalam pengajaran speaking, instruktur hanya menentukan topik dan membuat pertanyaan-pertanyaan pancingan terkait topik untuk membuat peserta berbicara dalam Bahasa Inggris. Tidak ada sesuatu yang membantu 
mereka dalam berbicara kecuali pertanyaan sang instruktur. Tabel TTS ini berfungsi untuk memandu pembelajar mengkontruksi kalimat dalam bahasa target, dalam hal ini Bahasa Inggris.

Dengan adanya panduan ini, diharapkan peserta pelatihan speaking Bahasa Inggris akan merasa lebih percaya diri dalam berbicara. Mereka akan memulainya dengan kalimat-kalimat sederhana, lalu berkembang menajadi kalimat-kalimat yang lebih lengkap bahkan bisa berkembang labi menjadi kalimat majemuk (complex sentence).

Penggunaan media pengajaran ini sangat membantu tidak hanya siswa tapi juga guru dalam menyampaikan materi pembelajaran menjadi lebik efektif. Pengajar akan merasa terpandu untuk menyampakai materi secara runut dan sistematis. Penyampaian materi akan dimulai dengan penjelasan grammatical, dilanjutkan dengan proses drilling terstruktur, dan selanjutnya bisa ditutup dengan kegiatankegiaatan productive seperti mengarang (written) atau membuat monolog (speaking).

Bagi pembelajar pemula, penggunaan tabel TTS ini dapat digunakan untuk meletakan tata bahasa dasar dalam pemikiran mereka. Hal ini akan mempermudah mereka mengembangkan keterampilan-keterampilan lain dalam Bahasa Inggris ditahap-tahap selanjutnya. Selain itu bentuk pengajaran yang praktis dan dilakukan secara gradual akan meningkatkan rasa percaya diri peserta didik dalam belajar.

\section{Penggunaan Istilah Linguistik dalam Design TTS}

Konten media pembelajaran TTS ini mengandung beberapa istilah linguistics. Namun demikian semuanya adalah istilah-istilah linguistik umum yang telah sangat populer ditengah masyarakat. Contohnya adalah subject, predicate dan complement. Penggunaan istilah ini bisa menjadi kekuatan tapi juga bisa membingungkan penggunanya. Terutama bagi mereka yang tidak memahaminya. Idealnya, penggunaan seluruh istilah dalam tabel adalah istilah-istilah umum yang telah populer di masyarakat.

Rekan-rekan sejawat berpendapat bahwa pada dasarnya penggunaan istilah-istilah tersebut sudah tepat. Namun demikian untuk mempermudah penggunaannya bisa istilah predikat diganti dengan "Verb" atau "kata kerja" dan istilah "Complement" dengan Bahasa Indonesia "Pelengkap". Penggunaan istilah dalam Bahasa Indonesia tidak akan mengurangsi esensi dan manfaat dari media pengajaran TTS ini.

\section{Penggunaan TTS diluar Pengajaran Speaking}

Salah seorang rekan sejawat berpendapat bahwa hal ini sangat dimungkinkan. Misalnya pada pembelajaran writing. Menurutnya dalam pembelajaran writing tidak terlepas dari proses merangkai kata dan penyusunan kalimat menjadi paragraf-paragraf. Dengan demikian kegiatan-kegiatan tersebut tetap memerlukan kompas untuk memberikan pedoman bagi peserta didik. Peneliti telah mencoba menggunakan media ini dalam pengajaran persiapan TOEFL, khususnya materi yang terkait struktur. Media ini dapat digunakan untuk menjelaskan materi-materi seperti subjek kalimat, predikat kalimat atau koordinat konjungsi dan subordinat konjungsi dalam kalimat-kalimat compound dan kalimat-kalimat majemuk.

Pada dasarnya media ini sangat mudah dikombinasikan dengan berbagai kegiatan pengajaran. Rekan sejawat lainnya berpendapat bahwa media ini dapat digunakan dalam metode lain selain drilling, misalnya metode TPR (Total Physical Response). Ide awal dari pembuatan design tabel pembelajaran TTS ini pun terilhami dari metode-metode seperti GTM (Grammar Translation Method) lalu dipadupadankan dengan kegiatan drilling. Maka tercetuslah ide Structured Drilling Method (SDM).

\section{Relevansi Penggunaan TTS di Kelas Intermediate dan Advance.}

Pertanyaan menarik selanjutnya adalah tingkat relevansi penggunaan media pembelajaran ini dalam tingkat-tingkat lanjutan seperti intermediate atau bahkan advance. Salah satu dari kolega memiliki pendapat bahwa penggunaan tabel ini akan sangat relevan di berbagai level. Tabel seperti ini akan selalu cocok digunakan untuk semua level. Namun menurutnya harus ada sedikit modifikasi penyesuaian disetiap levelnya. Isi dari tabel dalam media pembelajaran ini harus di-customize sesuai level kemampuan Bahasa penggunanya. Misalkan untuk level advance tidak perlu bicara simple sentence yang bertenses present tense dan atau tenses-tenses simple lainnya melainkan sudah masuk ke materi drilling complex sentence atau compound sentence. Media ini juga bisa digunakan untuk menjelaskan materi seperti 
If-Clause. Bahkan materi direct dan indirect speech, masih memungkinkan saja menggunakan media ini untuk pendekatan penyampaiannya. Pada dsarnya, isi dapat dikondisikan sesuai kebutuhan. Dengan kata lain sesungguhnya prisip-prinsip dasar dalam tabel ini berifat fleksibel yang bersifat terbuka dan sangat memungkinkan dilakukannya modifikasi.

18. Cakupan Media TTS Terhadap Materi Bahasa Inggris

Prinsipnya penggunaan media TTS ini adalah latihan membuat kalimat dengan bantuan polapola yang kalimat yang ada dalam tabel. Instruktur memberikan pancingan baik dengan pola translation dan question and answer. Dengan demikian, media ini akan terkait dengan materi-materi lainnya. Media ini misalnya dapat digunakan untuk mempelajari dan atau mendrill kalimat komperatif-superlatif. Kita juga bisa menggunakan media pembelajaran TTS ini untuk mengajarkan berbagai materi seperti preference, suggestion, obligation, compliment dan lain sebagainya.

Salah satu opini rekan sejawat mengatakan bahwa untuk level dasar dan sebagai materi pembuatan kalimat, konten dari TTS ini sudah sangat cukup. Namun untuk materi lain materi penggunaan media ini belumlah cukup. Sekali lagi kuncinya adalah penyesuaian. Kita harus mengcustomize dan melakukan sedikit modifikasi disesuaikan dengan keperluan dan penggunaan.

19. Kekuatan

Kesederhanaan pola-pola kalimat dalam tabel ini adalah ringkasan dari banyak materi yang dibuat kedalam satu tabel. Hal ini bisa membuat penyampaian materi tenses yang bisa berlembarlembar cukup disampaikan dalam bentuk satu tabel praktis saja. Tidak perlu penjelasan yang detai dan lengkap. Karena yang terpenting adalah, peserta didik mampu memproduksinya menjadi kalimatkalimat yang tepat dalam bahasa target.

Dari sisi komunikatif, tabel ini cukup komprehensif dan lengkap namun sangat sederhana. Kesederhanaannya lah yang akan membuat tabel ini mudah dihafal dan dipraktikannya. Selain itu sebenarnya konten pattern pada tabel ini bisa disesuaikan. Misalnya dengan menambahkan pola tenses lain dalam kolom predikatnya. Dengan demikian fleksibilitas adalah kekuatan lain dari Media pembelajaran TTS ini.

Menurut pandangan kolega kedua, beliau mencatat dua hal yang menurut pendapatnya merupakan kelebihan dari alat bantu ini antara lain: Alat bantu sangat efektif digunakan sebagaia media belajar dan pengajaran karena dengan media ini guru dan siswa tidak perlu membuat catatan berhalaman-halaman. Cukup membawa table ini dan dapat dimasukan kedalam kantong baju/celana. Kedua alat bantu ini sangat mudah dipahami oleh siswa karena didalam table ini sudah di mapping sesuai kebutuhan kalimat yang ingin diucapkan.

20. Kelemahan

Menurut pandangan kolega pertama, penggunaan media ini dalam jangka waktu yang lama akan menyebabkan kejenuhan sehingga perlu di variasikan dengan kegiatan-kegiatan lain. Selain itu metode drilling yang pada dasarnya merupakan metode pengulangan juga berpotensi menyebabkan kejenuhan.

Kolega kedua berpendapat bahwa materi tense adalah salah satu fosil material, jadi penggunaan alat bantu ini memang lebih cocok untuk membantu kalangan dasar; kalau diberikan di level yang salah maka akan terjadi suasana membosankan dalam kegiatan pembelajaran; dan selain itu cara penyampaian harus dengan cara yang energik.

21. Saran dan Masukan untuk Pengembangan Lanjutan

Ada berbagai masukan konstruktif yang disampaikan rekan sejawat untuk kemajuan dan pengembangan media pembelajaran ini. Misalnya salah satu rekan mengusulkan untuk mengkombinasikan gambar dalam tabel dasar ini. Dengan adanya gambar diharapkan adanya variasi yang lebih menarik penggunanya.

Peneliti mencatat bahwa hal ini sangat memungkin dilakukan. Mungkin material tabel yang sebelumnya hanyalah terbuat dari media digital printing diatas media triplek kayu bisa diubah menjadi material logam tertentu sehingga bisa menggaplikasikan magnet untuk membuat item-item dalam tabel jadi mudah di ganti dan bongkar pasang. 


\section{Kesimpulan}

1. Gambaran dasar media pembelajaran TTS ini adalah sebuah media pembelajaran yang didesign sedemian rupa, padat dan efektif namun cukup merangkum berbagai materi dalam pengajaran bahasa Inggris. Fungsinya adalah sebagai pedoman yang menuntun pembelajar memproduksi berbagai kalimat dalam Bahasa Inggris.

2. Design awal dari tabel TTS ini adalah sebuah tabel terdiri dari 3 kolom: Subject, predicate dan complement (SPC) yang didalamnya terdapat berbagai variasi kata kerja (noun) sebagai predikat dari setiap kalimat dalam Bahasa Inggris. Berbagai masukan dari sejawat sebaiknya berbagai istilah dalam design awal ini tidak perlu dibuat rigid. Sebaliknya, sebaiknya dibuat fleksibel sehingga dimungkinkan untuk dilakukan penyesuaian sesuai dengan kebutuhan dan pemahaman pengguna. Pemilihan material khusus perlu dilakukan untuk dapat menyesuaikan dengan kebutuhan ini.

3. Penggunaan media ini pun harus diikuti metode drilling khusus yang sementara ini dinamai "Structured Drilling Method" atau yang disingkat SDM. Penelitian khusus mengenai ini akan dilakukan pada serie penelitian selanjutnya.

4. Respon mayoritas peserta uji coba memberikan respon positif. Mayoritas responden merasa menjadi sangat mudah mempelajari speaking dengan bantuan media ini sehingga dapat disimpulkan media ini cukup efektif.

5. Begitupun para kolega pengajar pada dasarnya memberikan respon positif terkait dengan penggunaan media pengajaran TTS ini. Namun demikian mereka memberikan catatan membangun untuk pengembangan lanjutan, keduanya berpendapat pentingnya modifikasi. Prinsipnya media pengajaran ini harus mampu di customize sesuai dengan kebutuhan pengajaran.

\section{Daftar Pustaka}

Dananjaya, Utomo (2010). Media Pembelajaran Aktif. Bandung : Nuansa.

Dewey, John. (2004). Experience and Education (Pendidikan Berbasis Pengalaman). Jakarta: Taraju.

Frank, Marcella. (1972). Modern English Exercise for Non-Native Speakers. New Jersey : PranticeHall.

Kamal, S \& Novita Triana. (2011). Penggunaan Metode Drill dalam Pembelajaran Bahasa Inggris. Jurnal Bahasa dan Sastra. 1(2), 163-170.

Mardariyanti, Eka., Asfah Rahman \& Muh. Najib. (2014). Pengaruh Pembelajaran Drill Dalam Menumbuhkan Kemampuan Public Speaking (Retorika) Pembelajaran Bahasa Inggris Siswa SMAN 5 Makassar. Jumal Komunikasi Kareba. Vol. 3, No. 3.

Media Indonesia, (12 Desember 2019). Indeks Kemampuan Bahasa Inggris Orang Indonesia Nomor 61, 00.45 WIB.

Patton, Michael Quinn. (1980). Qualitative Evaluation and Research Methods. London.

Richards, Jack C.; Platt, John; Platt, Heidi. (1999). Longman dictionary of Language Teaching and Applied Linguistics. Singapore: Longman Group UK Limited

Richards, Jack C.; Rodgers, Theodore S. (1986). Approaches and Methods in Language Teaching. New York: Cambridge University Press.

Sardiman, A. M. (2006). Interaksi dan Motivasi Belajar Mengajar. Jakarta: PT Raja Grafindo Persada.

Sugiyono. (2008). Memahami Penelitian Kualitatif. Bandung : CV Alfabeta 